\title{
A new species of Gymnotus (Gymnotiformes: Gymnotidae) from the Fitzcarrald Arch of southeastern Peru
}

\author{
Emmanuel L. Maxime and James S. Albert
}

Herein Gymnotus chaviro is described from the Alto Yuruá (upper rio Juruá) of southeastern Peru, where it is locally abundant in terra firme streams and floodplain oxbow lakes, and occurs sympatrically and syntopically with the type species of the genus G. carapo. The new species is diagnosed by a unique combination of morphometric, meristic, and osteological traits, and a characteristic color pattern in which the dark band-pairs are unbranched and incompletely separated, and the pale inter-bands rarely reach to the dorsal mid-line on the anterior half of the body, being crescent-shaped in abdominal area. Gymnotus chaviro is a member of the G. carapo species group, with which it shares the presence of two pores in the dorsolateral portion of the preopercle, dark pigment bands with wavy margins that become broken and/or loose contrast with the ground color through growth, a clear patch at the caudal end of an otherwise darkly pigmented anal fin, and more than four arrowhead-shaped (anteroposteriorly compressed) teeth in the anterior portion of the dentary. Gymnotus chaviro is most similar in external appearance to G. curupira of lowland Western Amazonia in possessing a slender lateral profile (mean body depth less than 9\% total length), a similar color pattern (median number of bands 19 with bands less distinct on dorsum), a large inter-orbital distance (mean greater than $41 \%$ head length), a broad head (mean head width greater than $65 \%$ head length) and a large mouth (mean mouth width greater than $43 \%$ head length). This new species can also be distinguished from $G$. curupira by the configuration of the preopercular pores, and by several meristic traits of squamation and fin rays. This is the first gymnotiform species described from the interior of the Fitzcarrald Arch, and the only gymnotiform species known to date that is endemic to this upland region of the western Amazon.

En el presente trabajo se describe Gymnotus chaviro de Alto Yuruá (parte alta del Río Juruá) en el sureste de Peru. Esta especie es abundante en arroyos de tierra firme y llanuras con lagos en herradura, ocurre de manera sintópica y simpátrica con la especie tipo del genero, G. carapo. La nueva especie se diagnostica por una combinación única de rasgos morfométricos, merísticos y osteológicos, así como un patrón característico de bandas pares obscuras no ramificadas e incompletamente separadas, alternando con bandas claras que raramente alcanzan el centro de la línea dorsal en la mitad anterior del cuerpo adquiriendo forma de media luna en la parte abdominal. Gymnotus chaviro es un miembro del grupo de especies de G.carapo, con quien comparte la presencia de dos poros en la porción dorso lateral del preopérculo, bandas con pigmentos obscuros con márgenes ondulados que se parten y/o pierden el contraste con el color de fondo a medida que crece, aleta anal obscura con un claro parche de un pigmento obscuro en borde caudal y más de cuatro dientes en forma de punta de flecha (anteroposteriormente comprimidos) en la porción anterior del dentario. Gymnotus chaviro es más parecido en apariencia externa a $G$. curupira de las planicies del Oeste Amazonia por tener un perfil lateral esbelto (media de la profundidad del cuerpo es menor al 9\% del largo total), un patrón de color similar (promedio de 19 bandas con otras menos notables en el dorso) una distancia inter-orbital grande (media mayor al $41 \%$ de longitud de cabeza), cabeza ancha (media mayor al $65 \%$ de la longitud de cabeza) una boca grande (media del ancho mayor al $43 \%$ de la longitud de cabeza). Esta especie también se diferencia de G. curupira por la configuración de los poros pre-operculares y por varios rasgos en las escamas y numero de radios en las aletas. Esta es la primera especie de gymnotiforme descrita del interior del Arco de Fitzcarrald y la única especie de gymnotiforme conocida a la fecha, que es endémica de la región alta de Amazona occidental.

Key words: Amazon, Biodiversity, Electric fish, Neotropical fish.

${ }^{1}$ Department of Biology, University of Louisiana at Lafayette, Lafayette, LA, 70504-2451, USA. exm4197@louisiana.edu, jalbert@louisiana.edu 


\section{Introduction}

Gymnotus Linnaeus is the most species-rich genus of Neotropical electric fishes (Gymnotiformes) with 34 species currently recognized, and many additional undescribed species known from museum collections (Albert, 2001; Albert et al., 2004; Albert \& Crampton, 2005; Lovejoy et al., 2009). Gymnotus species exhibit considerable morphological and ecological diversity, ranging in mature body size over an order of magnitude (approx. 10-100 cm), and occupying most freshwater habitats throughout the lowland Neotropics excluding deep river channels (Crampton \& Albert, 2006). Gymnotus also has the widest geographic range of all gymnotiform genera, from southern Mexico (Albert \& Miller, 1995) south to the pampas of northern Argentina (Casciotta et al., 1989). Gymnotus exhibits its highest diversity in the lowlands of western Amazonia from where 15 species have been described (Albert et al., 2004). The diversity of Gymnotus in adjacent upland areas of the Andean Piedmont is less well known, due in part to logistic difficulties of sampling these remote regions, and perhaps also to more restricted range distributions in upland areas (Albert \& Crampton, 2005; Ribeiro, 2006).

Herein we describe a new species of Gymnotus discovered as part of a project to survey and document the aquatic fauna of the Alto Purús National Park. This park is located in poorly known region of high species endemism in southeastern Peru that straddles the headwaters of four of the largest tributary basins in the western Amazon; the Ucayali, Juruá (Yuruá), Purús and Madeira rivers. The upper reaches of these rivers are hydrologically isolated from one another across their watershed divides, and are also at least partially isolated from the rest of lowland Amazonia by rapids and by distance. This whole upland region is known as the Fitzcarrald Arch, and is thought to have been uplifted in association with Miocene-Pliocene rise of the Peruvian Andes (Westaway, 2006; Espurt et al., 2007).

The new species is a member of the G. carapo group (sensu Albert et al., 2004), a clade of at least 19 species that share the following set of derived character states: 1) two laterosensory canal pores in the dorsolateral portion of the preopercle, 2) irregular, wavy dark pigment bands which usually become broken and/or lose contrast with the ground color through growth, 3) a clear patch of membrane at the caudal end of an otherwise darkly pigmented anal fin (more pronounced in juveniles), and 4) more than four arrowhead-shaped (anteroposteriorly compressed) teeth in the anterior portion of the dentary. The description of the new species provided here is based on features of external morphology, pigmentation and osteology, and brings one more species to the G. carapo species group, and the total number of Gymnotus species to 35 (Table 1).

\section{Material and Methods}

Specimens of the type series were captured in the upper portions of the río Yuruá in the department of Ucayali in Perú. The río Yuruá arises in the Department of Ucayali in Perú and runs into Brazil where it is known as rio Juruá, a tributary to the Amazon that contributes about 4\% of the total Amazon discharge (Goulding et al., 2003). The Peruvian portion of the río Yuruá meanders across a floodplain of moderate breadth (ca. $1 \mathrm{~km}$ ) with numerous oxbow lakes, flowing in a generally northward direction.

Fieldwork was conducted from July 20 to August 11, 2008, for a period of 20 days during the dry season, in the area of the town of Breu $\left(09^{\circ} 31.175 \mathrm{~S} 72^{\circ} 45.755 \mathrm{~W}, 271 \mathrm{~m}\right)$ on the Alto Yuruá river in southeastern Peru. Collections were made using seine nets (5, 10 and $20 \mathrm{~m}, 5 \mathrm{~mm}$ between knots), dip nets, cast nets, traps, and hook and line. A local fish-toxin called huaca extracted from leaves of Clibadium remotiflorum (Asteraceae) was used to dislodge specimens from log jams in larger streams. Specimens were collected in runs and pools of small terra firme streams and floodplain oxbow lakes, and never on beaches or channels of the main river. All collecting stations were georeferenced (latitude, longitude, altitude) using GPS, and habitats were documented with high resolution digital photographs and written descriptions.

High resolution (5 MB) digital images were captured using a Nikon Coolpix 5000 camera in macro-mode against a neutral blue background, under flash or natural light, and usually with the aid of a thin sheet serving as a light diffuser to reduce contrast and shadows. Specimens were then measured fixed in $10 \%$ formalin for at least 48 hours in a covered flat plastic tray and later transferred to $70 \%$ ethanol in the laboratory.

Measurements and counts follow Albert \& Crampton (2003). All measurements were taken with digital calipers to the nearest $0.1 \mathrm{~mm}$. Osteological data were taken from specimens cleared and stained (c\&s) following the technique described by Taylor \& Van Dyke (1985). Size of specimens is reported as total length (TL) in mm from the snout to tip of tail. Sexual maturity was determined from examination of gonads in freshly preserved specimens under a dissecting microscope. Morphometric measurements are reported as percentage TL or HL and were not taken from specimens with a damaged caudal appendage or those with incomplete regeneration. Institutional abbreviations follow Ferraris Jr. (2007).

\section{Gymnotus chaviro, new species Figs. 1- 2}

Holotype. MUSM 33715, 233 mm. Peru, Dept. Ucayali, Quebrada Dos y medio, a small terra firme stream ca. $2 \mathrm{~km}$ NW the town of Breu, on the Alto Yuruá River, 09³1.175S 7245.755W, $271 \mathrm{~m}$ elevation, 20 Jul, 2008, J. S. Albert, R. Quispe \& I. Corahua.

Paratypes. Peru, all collected with holotype: MUSM 33714, 40, 4 c\&s, 95-275 mm; FMNH 118274, 10, 134-179 mm; CAS 227893, 10, 123-150 mm; MCZ 168419, 10, 115-160 mm; MCP 43880, 10, 116-164 mm; MZUSP 103035, 10, 130-217 mm; AMNH 248884, 10, $104-180 \mathrm{~mm}$.

Nontype specimens. All from Peru. MUSM 1406, 1, 127 mm, Madre de Dios, Parque Nacional Manú, Quebrada Pabitza, Aguajal. MUSM 1759, 2, 142-150 mm, Madre de Dios, Puerto Maldonado, 
river near Tambopata, Cochachica. MUSM 21405, 1, 138 mm, Madre de Dios. MUSM 22731, 10, 2 c\&s, 143-210 mm, Madre de Dios drainage. MUSM 16662, 1, 325 mm, Madre de Dios, Tambopata, Madre de Dios drainage, lago Copamanu.

Diagnosis. Gymnotus chaviro is unique among members of the G. carapo group (sensu Albert et al., 2004) in having a color pattern composed of oblique, dark, unbroken pigment bands along the length of the body, dark band-pairs with wavy, irregular margins, mainly unbranched or incompletely separated, pale inter-bands rarely reaching to the dorsal midline on the anterior half of the body and crescent-shaped in abdominal area.

Gymnotus chaviro can further be distinguished from all congeners by the following unique combination of morphometric and meristic traits: 1, 17-22 oblique bands (vs.
24-26 in G. chimarrao); 2, clear (unpigmented) patch of membrane at the caudal end of the anal-fin in specimens ( $v s$. even pigmentation in G. cylindricus and G. pantherinus groups, or striped in G. tigre group); 3, anal fin pale gray (vs. black in G. carapo, G. arapaima, G. ucamara); 4, several (4-5) arrow-head shaped teeth at anterior end of the dentary (vs. all conical in G. cylindricus and G. pantherinus groups, or five or more in most members of $G$. carapo group); 5, body depth 6.3-10.2\% TL (vs. 10.3-13.1\% in G. sylvius); 6, mouth width 35.5-52.5\% HL (vs. 26.9-28.1 in G. diamantinensis); 7, interorbital distance $37.9-49.2 \%$ HL (vs. $28.6-36.5 \%$ in $G$. arapaima and in G. choco); 8, head depth 61.8-89.0\% HL (vs. 54.4-61.8\% in G. choco and G. sylvius); 9, head width 58.574.7\% HL (vs. 51.1-51.3\% in G. diamantinensis); 10, pectoral fin length 45.8-66.8\% HL (vs. 36.3-41.1 in G. diamantinensis); 11, pectoral-fin rays 18-19 (vs. 13-17 in G. carapo, G. ucamara,

Table 1. Valid species of Gymnotus with geographic range by drainage basin and habitat. Species arranged alphabetically. Distributional regions: EA, Eastern Amazon (including lower Negro, Trombetas, Tapajós, Tocantins); GO, Guianas-Orinoco (including Trinidad, upper Negro above São Gabriel); MA, Middle America; UM, Upper Madeira (including Mamoré, Guaporé, Beni, Madre de Dios); NE, Northeastern Brazil (from São Francisco to Jequitinhonha); NW, Northwestern South America (including Magdalena and Maracaibo); PA, Paraguay-Paraná and Uruguay; PI, Piauí (including Itapicuru and Parnaíba); PS, Pacific slope Colombia and Ecuador; RO, Roraima (including Branco); SE, Southeast coast Brazil; WA, Western Amazon (including affluents west of mouth of Purús). Habitat = TF, terra firme; WF, whitewater floodplain (várzea); BF, blackwater floodplain.

\begin{tabular}{|c|c|c|c|}
\hline Species & Authors & Distribution & Habitat \\
\hline G. anguillaris & Hoedeman, 1962 & GO & $\mathrm{TF}, \mathrm{BF}$ \\
\hline G. arapaima & Albert \& Crampton, 2001 & WA & TF, BF, WF \\
\hline G. ardilai & Maldonado \& Albert, 2004 & NW & TF \\
\hline G. bahianus & Campos-da-Paz \& Costa, 1996 & NE & $\mathrm{TF}$ \\
\hline G. carapo & Linnaeus, 1758 & $\begin{array}{c}\text { EA, GO, UM, PI, } \\
\text { RO, WA, NE }\end{array}$ & TF, BF, WF \\
\hline G. cataniapo & Mago-Leccia, 1994 & GO & $\mathrm{TF}, \mathrm{BF}$ \\
\hline G. chaviro & Maxime \& Albert, this paper & WA, UM & TF, WF \\
\hline G. chimarrao & Cognato, Richer-de-Forges, Albert \& Crampton, 2007 & SE & $\mathrm{TF}$ \\
\hline G. choco & Albert, Crampton \& Maldonado, 2003 & PS & $\mathrm{TF}$ \\
\hline G. coatesi & LaMonte, 1935 & EA, WA & $\mathrm{TF}$ \\
\hline G. coropinae & Hoedeman, 1962 & GO, EA, WA & $\mathrm{TF}$ \\
\hline G. curupira & Crampton, Thorsen \& Albert, 2005 & WA & $\mathrm{TF}$ \\
\hline G. cylindricus & LaMonte, 1935 & MA & $\mathrm{TF}$ \\
\hline G. diamantinensis & Campos-da-Paz, 2002 & EA & $\mathrm{TF}$ \\
\hline G. esmeraldas & Albert \& Crampton, 2003 & PS & $\mathrm{TF}$ \\
\hline G. henni & Albert, Crampton \& Maldonado, 2003 & PS & $\mathrm{TF}$ \\
\hline G. inaequilabiatus & Valenciennes, 1847 & PA & WF \\
\hline G. javari & Albert, Crampton \& Hagedorn, 2003 & WA & $\mathrm{TF}, \mathrm{BF}$ \\
\hline G. jonasi & Albert \& Crampton, 2001 & WA & WF \\
\hline G. maculosus & Albert \& Miller, 1995 & MA & $\mathrm{TF}$ \\
\hline G. mamiraua & Albert \& Crampton, 2001 & WA & WF \\
\hline G. melanopleura & Albert \& Crampton, 2001 & WA & WF \\
\hline G. obscurus & Crampton, Thorsen \& Albert, 2005 & WA & WF \\
\hline G. omarorum & Richer-de-Forges, Crampton \& Albert, 2009 & PA & TF \\
\hline G. onca & Albert \& Crampton, 2001 & WA & WF \\
\hline G. panamensis & Albert \& Crampton, 2003 & MA & $\mathrm{TF}$ \\
\hline G. pantanal & Fernandes, Albert, Daniel-Silva, Lopes, Crampton \& Almeida-Toledo, 2005 & PA, UM & TF, WF \\
\hline G. pantherinus & Steindachner, 1908 & SE & $\mathrm{TF}$ \\
\hline G. paraguensis & Albert \& Crampton, 2003 & PA & WF \\
\hline G. pedanopterus & Mago-Leccia, 1994 & GO & TF, BF \\
\hline G. stenoleucus & Mago-Leccia, 1994 & GO, EA & $\mathrm{TF}, \mathrm{BF}$ \\
\hline G. sylvius & Albert, Fernandes-Matioli \& Almeida-Toledo, 1999 & $\mathrm{PA}, \mathrm{SE}$ & TF, WF \\
\hline G. tigre & Albert \& Crampton 2003 & EA, WA & WF \\
\hline G. ucamara & Crampton, Lovejoy \& Albert, 2003 & WA & WF \\
\hline G. varzea & Crampton, Thorsen \& Albert, 2005 & WA & WF \\
\hline
\end{tabular}




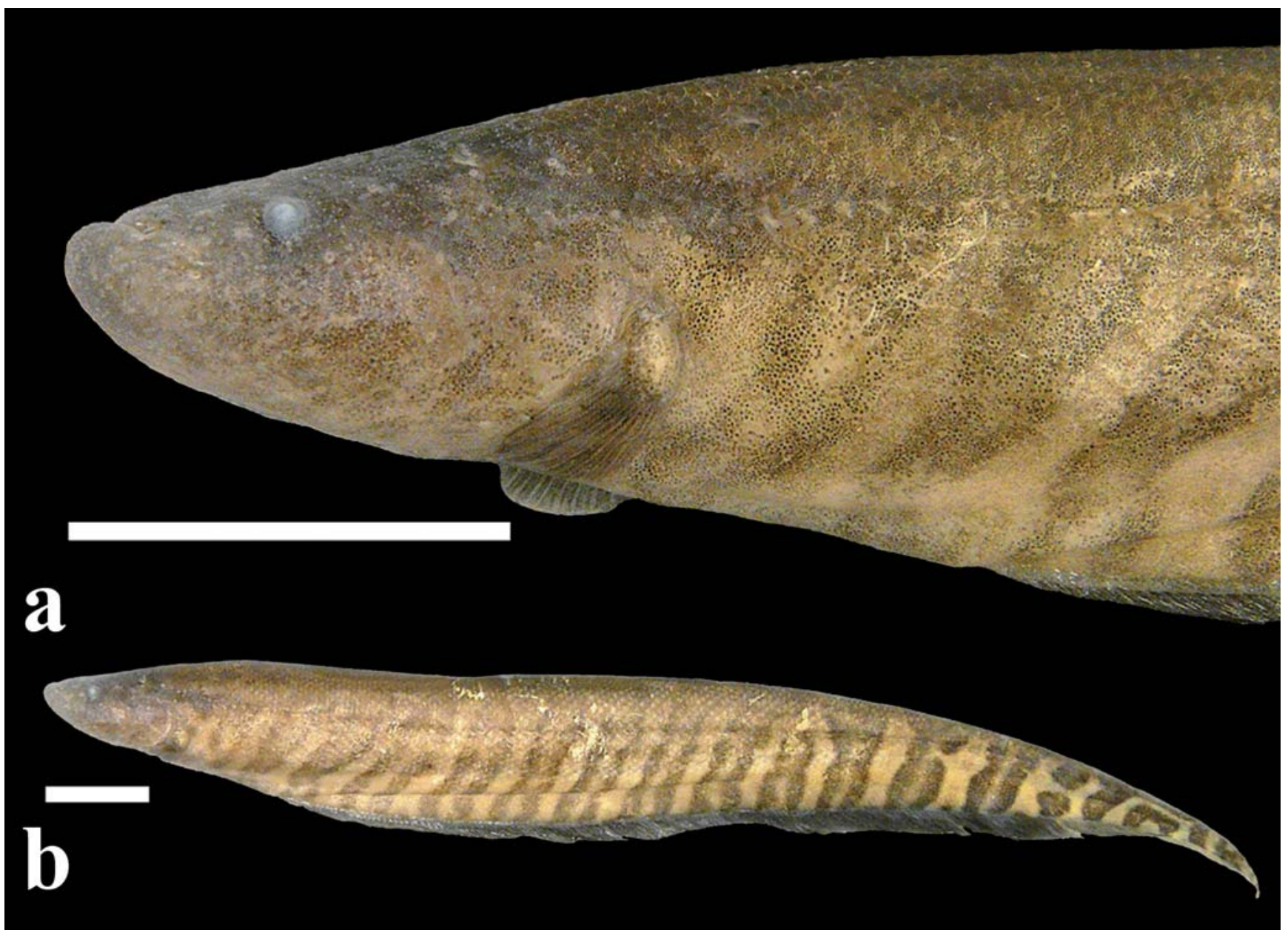

Fig. 1. Gymnotus chaviro, holotype, MUSM 33715, $233 \mathrm{~mm}$ TL. (a) head, (b) body. Scale bars $=20 \mathrm{~mm}$.

G. sylvius, G. mamiraua, G. diamantinensis, G. choco, G. bahianus, G. arapaima, G. omarorum, G. chimarrao, vs. 20-22 in G. obscurus); 12, pored lateral-line scales to first ventral ramus 48-52 (vs. 32-39 in G. mamiraua, 40-41 in G. bahianus, 40 in G. chimarrao, and 24-35 in G. omarorum); 13 , head length 8.9-12.0\% TL (vs. 12.2-15.8\% in G. arapaima and G. ucamara); 14 , number of ventral lateral-line rami 7-12 (vs. 16-37 in G. chimarrao and G. omarorum); 15, anal-fin rays 228-280 (vs. 180-213 in G. chimarrao and G. tigre); 16, caudal rows of electroplates 4 (vs. 3 in G. diamantinensis and G. choco); and 17, number of scales above the lateral line 7-9 (vs. 6 in $G$. ucamara).

Gymnotus chaviro is most similar in external appearance to G. curupira from the western Amazon, from which it may be distinguished by the presence of two (rarely one) pores in the dorsoposterior corner of preopercle ( $v s$. always one pore), fewer total pored lateral-line scales 86-100 (vs. 104-140), fewer pored lateral-line scales to the first ventral ramus (48-52 vs. 59-62), more pectoral-fin rays (18-19 vs. 16-17), and more electrocyte tubes (4 rows vs. 3) in the caudal region. Gymnotus chaviro is also similar in external appearance to $G$. varzea from the western Amazon from which it may be distinguished by more teeth on the dentary (16 vs. 11-12) and more teeth on the premaxilla (10 vs. 6-7). Gymnotus chaviro is also similar in external appearance to G. pantanal from Paraguay from which it may be distinguished by an incomplete separation of the dark pigment bands (vs. no separation), white interbands about as broad as dark bands (vs. no larger than one third), fewer dark bands (17-22 vs. 22-26), more scales over anal-fin pterygiophores (12-13 vs. 10-11), and fewer ventral lateralline rami (7-12 vs. 14-23).

Description. Morphometric and meristic data (Table 2) were pooled from 89 specimens of type-series. Size up to $275 \mathrm{~mm}$. No secondary sexual dimorphism observed in body shape or anatomy. Scales cycloid, ovoid, present on entire post-cranial portion of body from nape to tip of caudal appendage, large above lateral line small, over anal fin pterygiophores. Mouth superior, lower jaw extending beyond upper one, rictus decurved. Chin fleshy and bulbous with thick support tissues overlying tip of snout and oral jaws. Eyes below horizontal midline. Anterior narial pore pipe-shaped, located within gape. Anterior nares small, approximately 4-5 times smaller than diameter of eye. Gape never extended beyond posterior nares even in largest specimens. Posterior narial pore flush with head surface, circumorbital series ovoid. 


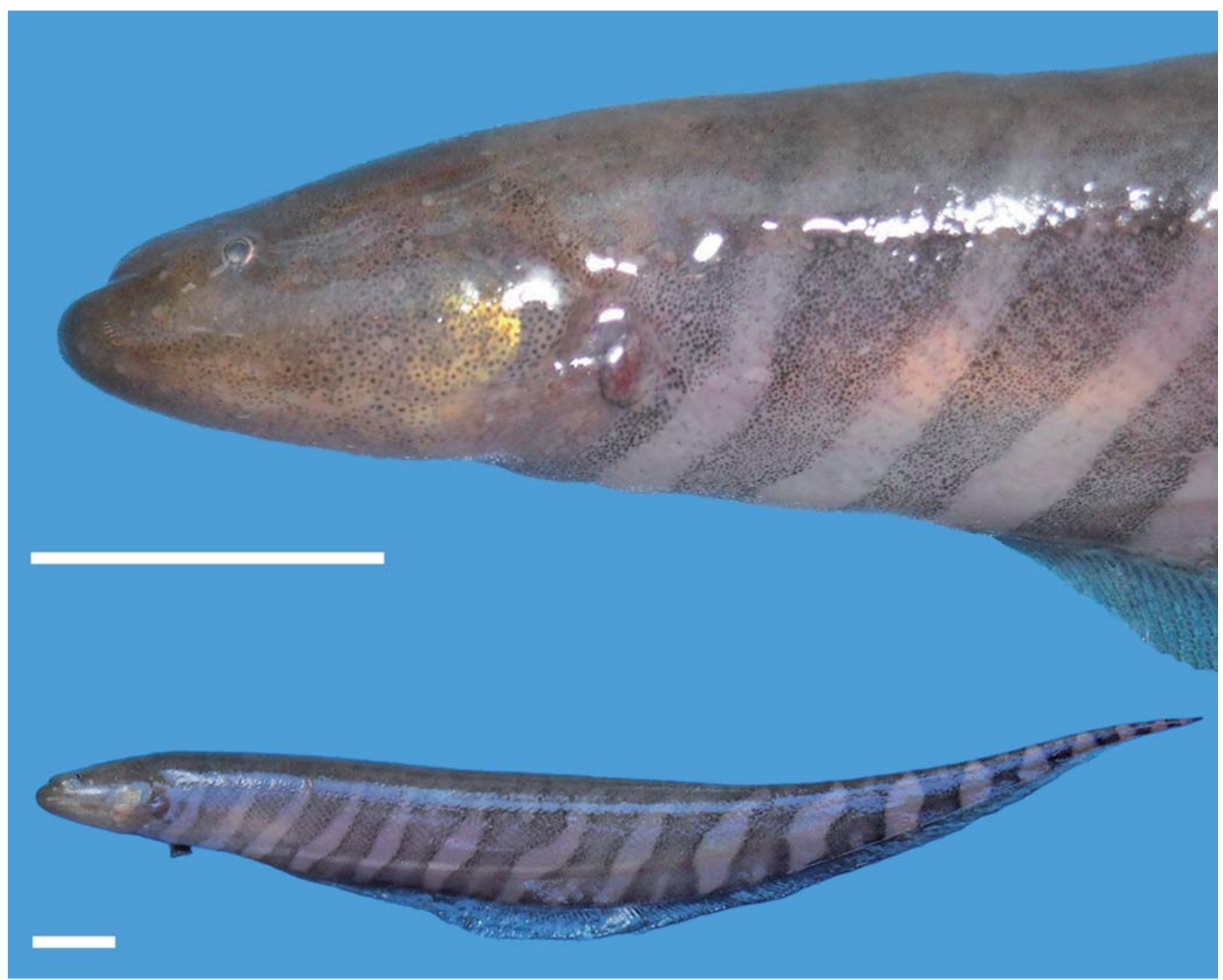

Fig. 2. Gymnotus chaviro, paratype, MUSM 33714, $150 \mathrm{~mm}$ TL. (a) head, (b) body. Scale bars = $10 \mathrm{~mm}$.

Maxilla and palatine near tip of mesopterygoid. Maxilla oriented vertically, rod-shaped, narrow distally with a length of dentary portion bearing 7-9 tooth sockets. Premaxilla with two rows of teeth with few of them in outer row (less than 10), and curved median margin. Mandible short, dentary teeth flattened anteroposteriorly along long axis of oral margin of dentary grading to conical posteriorly, with 14 arrowheadshaped teeth in outer row and 10 in an anterior inner tooth patch. Ventroposterior hook-like process at mental symphysis. Opercular dorsal margin convex, its posterior margin smooth. Two closely-positioned laterosensory pores (rarely one) in dorsoposterior corner of preopercle, associated cutaneous laterosensory pores well separated. Ascending mesopterygoid process contacting orbitosphenoid, arched mediolateraly. Dorsal region of hyomandibula with four lateral foramenae, supraorbital and infraorbital nerves divided. Hyomandibular posterior lateral-line foramen contacting posterior margin. Neurocranium with approximately triangular aspect in dorsal view, with narrow ethmoid region. Cranial fontanels closed.
Mesethmoid anterior margin with paired anterolateral processes. Four tubes (rows) of electroplates at one HL distance from tip of caudal appendage. 37-38 precaudal vertebrae (including those of Weberian apparatus).

Coloration. Ground color yellowish. 17 to 22 (mode 20) oblique and non broken (or incompletely broken in largest specimen) pigment bands (gray) with irregular wavy margins on lateral surface extending from nape and pectoral-fin base to tip of caudal appendage and oriented either vertically or obliquely in an antero-ventral to postero-dorsal diagonal. Anterior most 2 to 3 pale interbands crescent-shaped. Majority of dark bands paired with pale middle region (intraband), dark bands approximately as wide as pale interbands. Dark bands above lateral line continuous on anterior half of body, not visible against dark ground color on dorsal midline. Pigment density greater at band margins than in middle. Band-interband contrast sharper caudally and bands thinner anteriorly. Most bands are not well divided, intraband formed by less density 
Table 2. Morphometric and meristic data for Gymnotus chaviro. BW/BD expressed as a ratio.

\begin{tabular}{|c|c|c|c|c|}
\hline & $\mathrm{n}$ & Min. & Max. & Mean \\
\hline Total length (mm) & 97 & 95.0 & 275.0 & 148.7 \\
\hline Head length (mm) & 77 & 10.3 & 32.0 & 15.1 \\
\hline \multicolumn{5}{|l|}{ Percentage of total length } \\
\hline Head length & 72 & 8.9 & 12.0 & 10.3 \\
\hline Body depth (BD) & 71 & 6.3 & 10.2 & 8.8 \\
\hline Body width (BW) & 72 & 5.9 & 8.4 & 6.8 \\
\hline Anal fin length & 77 & 75.0 & 83.8 & 80.5 \\
\hline \multicolumn{5}{|l|}{ Percentage of head length } \\
\hline Head depth & 75 & 61.8 & 78.1 & 71.0 \\
\hline Head width & 76 & 58.5 & 74.7 & 68.7 \\
\hline Preorbital distance & 77 & 31.4 & 39.8 & 35.1 \\
\hline Postorbital distance & 77 & 58.4 & 67.3 & 63.2 \\
\hline Interorbital distance & 76 & 37.9 & 49.2 & 41.8 \\
\hline Mouth width & 76 & 35.5 & 52.5 & 43.4 \\
\hline Preanal length & 74 & 67.8 & 99.4 & 80.0 \\
\hline Pectoral fin length & 77 & 45.8 & 66.8 & 56.9 \\
\hline \multirow[t]{2}{*}{$\underline{\mathrm{BW} / \mathrm{BD}}$} & 73 & 0.64 & 0.88 & 0.77 \\
\hline & $\mathrm{n}$ & Min. & Max. & Median \\
\hline Bands & 87 & 17 & 22 & 19 \\
\hline Pored lateral line scales to $1^{\text {st }}$ ramus & 7 & 48 & 52 & 50 \\
\hline Total pored lateral line scales & 8 & 86 & 100 & 97 \\
\hline Lateral-line ventral rami & 6 & 7 & 12 & 9 \\
\hline \multirow[t]{2}{*}{ Anal-fin rays } & 24 & 239 & 280 & 258 \\
\hline & & & & Mode \\
\hline Scales above lateral line & 21 & 7 & 9 & 8 \\
\hline Anal-fin pterygiophore scales & 20 & 12 & 13 & 12 \\
\hline Pectoral-fin rays & 29 & 18 & 19 & 19 \\
\hline Precaudal vertebrae & 2 & 37 & 38 & - \\
\hline
\end{tabular}

of pigments at the middle of the band, no sharp band-intraband contrast. Three to four dark bands meet irregularly at ventral midline in region anterior to anal-fin origin. Juveniles possess more regularly arrayed alternating pigment bands with sharper band-interband contrast.

Head never banded, spotted or blotched, strongly countershaded with dense speckling dorsally fading to pale yellow ventrally. No rosy hue visible to operculum from underlying gills in juveniles. Pectoral-fin rays and interradial membranes uniform light gray. Anal fin membrane never blotched, spotted or marked. Anal fin membrane lightly and evenly pigmented with scattered chromophores along most of its length, fading to an absence of chromophores caudally.

Preservational artifacts. After capture specimens were either fixed immediately in $10 \%$ unbuffered formalin, or transported live to a field base in buckets for processing (i.e., photography and tissue sampling) before fixation. Some differences in coloration and superficial appearance were observed among specimens subjected to these different preservational treatments. Specimens fixed immediately after capture exhibit the following traits: 1 , pigments bands with high contrast dark brown ground color and yellow interbands (vs. low contrast); 2, body surface (skin of head and scales) lighter and more reflective due to a thicker mucous layer, scale margins less visible; 3 , head orientation straight (vs. recurved or arched); 5, laterosensory pores small, their margins flush with surrounding body surface (vs. large with bulging margins); 6, lens black (vs. hyaline), Specimens subjected to different preservational treatments did not differ in morphometric, meristic or osteological traits, or in the diagnostic aspects of coloration.

Geographic distribution. The type series of Gymnotus chaviro is known from the upper Yuruá basin, Department Ucayali, Peru (Fig. 3) and the Manu and Tampobata rivers of the Madre de Dios basin, Department Madre de Dios, Peru.

Ecological notes. Gymnotus chaviro inhabit pools and runs of small terra firme streams as they enter the floodplain, and the vegetated margins of flooplain lakes, with substrates of leaf litter and organic rich mud. Specimens are most dense in submerged stems and roots of aquatic grasses (e.g., Oryza spp.) and floating macrophytes (e.g., Eichornia crassipes). At the period of low water (August) when collections were made, specimens were very abundant, aggregated closely together, and were not distributed into discrete territories. The holotype was collected in a small terra firme stream $(1.2 \mathrm{~m}$ deep, $2.5 \mathrm{~m}$ wide, $25^{\circ} \mathrm{C}$ ) with a muddy bottom and deeply undercut banks, about $1 \mathrm{~km}$ from the edge of the floodplain.

Local Name. Anguilla, Spanish for eel.

Etymology. From the common name for Gymnotus in the language of the Asheninka indigenous people (Arawak/ Maipurean language family). A noun in apposition.

Remarks. Types specimens were restricted to localities in the Yuruá basin. Specimens from the Manu and Tampobata basins are excluded from the type series.

Comparative examined material. Materials examined are listed in Campos-da-Paz \& Costa (1996), Albert (2001), Albert \& Crampton (2001, 2003), Campos-da-Paz (2002), Crampton et al. (2003, 2005), Maldonado-Ocampo \& Albert (2003), Fernandes et al. (2005), Cognato et al. (2007), and Richer-deForges et al. (2009).

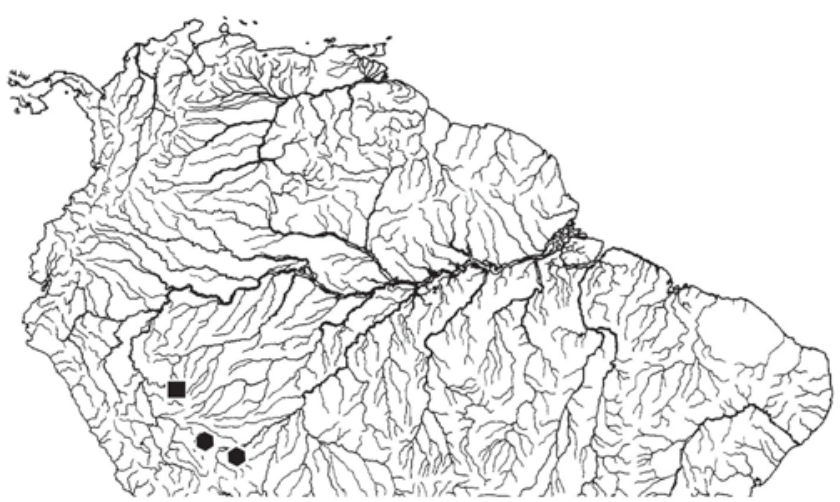

Fig. 3. Map of part of South America showing the known geographic distribution of Gymnotus chaviro. Type locality indicated by square symbol. Base map by M. Weitzman. 


\section{Acknowledgements}

We thank Isabel Corahua and Roberto Quispe for field assistance, and Tiago Carvalho, Hernan Ortega and Blanca Rengifo for discussions. Karsten Hartel (MCZ), Luiz Malabarba (UFRGS), Hernan Ortega (MUSM), Roberto Reis (MCP), and Leo Smith (FMNH) provided access to specimens and collection information. Alfy Morales provided the Spanish translation of the abstract. For collaboration in the field and intellectual camaraderie we thank Laurie Anderson, Io Almagro, Francisco Brusa, Cristina Damborenea, and Carolina Noreña. Collections were made under permit from the Peruvian Ministry of the Environment (INRENA) Carta No: 1312-2007-INRENA. This research was supported by National Science Foundation grants 0614334 and 0741450 .

\section{Literature Cited}

Albert, J. S. 2001. Species diversity and phylogenetic systematics of American knifefishes (Gymnotiformes, Teleostei). Miscellaneous Publications, Museum of Zoology, University of Michigan, 190: 1-129.

Albert, J. S. \& W. G. R. Crampton. 2003. Seven new species of the Neotropical electric fish Gymnotus (Teleostei, Gymnotiformes) with a redescription of G. carapo (Linnaeus). Zootaxa, 287: 154.

Albert, J. S. \& W. G. R. Crampton. 2005. Diversity and phylogeny of Neotropical electric fishes (Gymnotiformes). Pp. 360-409. In: Bullock, T. H., C. D. Hopkins, A. N. Popper \& R. R. Fay (Eds.). Electroreception. Vol. 21. New York, Springer Handbook of Auditory Research, 485p.

Albert, J. S., W. G. R. Crampton, D. H. Thorsen \& N. R. Lovejoy. 2004. Phylogenetic systematics and historical biogeography of the Neotropical electric fish Gymnotus (Teleostei: Gymnotiformes). Systematic and Biodiversity, 2: 375-417.

Albert, J. S. \& R. R. Miller. 1995. Gymnotus maculosus, a new species of electric fish (Chordata: Teleostei: Gymnotoidei) from middle America, with a key to species of Gymnotus. Proceedings of the Biological Society of Washington, 108: 662-678.

Campos-da-Paz, R. 2002. Gymnotus diamantinensis, a new species of electric knifefish from upper rio Arinos basin, Brazil (Ostariophysi: Gymnotidae). Ichthyological Exploration of Freshwaters, 13: 185-192.

Campos-da-Paz, R. \& W. J. E. M. Costa. 1996. Gymnotus bahianus sp. nov., a new gymnotid fish from Eastern Brazil (Teleostei: Ostariophysi: Gymnotiforms), with evidence for the monophyly of the genus. Copeia, 1996(4): 937-944.

Casciotta, J. R., H. L. López, R. C. Menni \& A. M. Miquelarena. 1989. The first fish fauna from the Salado River (Central Argentina, South America) with additions to the Dulce River and limnological comments. Archivos Hydrobiologia, 115: 603-661.

Cognato, D., M. Richer-de-Forges, J. S. Albert \& W. G. R. Crampton. 2007. Gymnotus chimarrao: a new species of electric fish (Gymnotiformes: Gymnotidae) from Southern Brazil. Ichthyological Exploration of Freshwaters, 18(4): 375-382.

Crampton, W. G. R. \& J. S. Albert. 2006. Evolution of electric signal diversity in gymnotiform fishes. Pp. 641-725. In: Ladich, F., S. P. Collin, P. Moller \& B.G. Kapoor (Eds.). Communication in Fishes. Enfield, Science Publishers Inc., 870p.
Crampton, W. G. R., D. H. Thorsen \& J. S. Albert. 2005. Three new species from a diverse, sympatric assemblage of the electric fish Gymnotus (Gymnotiformes: Gymnotidae) in the lowland Amazon Basin, with notes on ecology. Copeia, 2005(1): 82-99.

Espurt, N., P. Baby, S. Brusset, M. Roddaz, W. Hermoza, V. Regard, P. O. Antoine, R. Salas-Gismondi \& R. Bolanos. 2007. How does the Nazca Ridge subduction influence the modern Amazonian foreland basin? Geology, 35: 515-518.

Fernandes, F. M. C., J. S. Albert, M. D. Z. Daniel-Silva, C. E. Lopes, W. G. R. Crampton \& L. F. Almeida-Toledo. 2005. A new Gymnotus (Teleostei: Gymnotiformes: Gymnotidae) from the Pantanal Matogrossense of Brazil and adjacent drainages: continued documentation of a cryptic fauna. Zootaxa, 933: 1-14.

Ferraris Jr., C. J. 2007. Checklist of catfishes, recent and fossil (Osteichthyes: Siluriformes), and catalogue of siluriform primary types. Zootaxa, 1418: 1-300.

Goulding, M. J., R. Barthem \& E. J. G. Ferreira. 2003. The Smithsonian Atlas of the Amazon. Washington, Smithsonian Books, 255p.

Lovejoy, N. R., K. Lester, W. G. R. Crampton \& J. S. Albert. 2009. Phylogeny, biogeography, and electric signal evolution of Neotropical electric fishes of the genus Gymnotus (Osteichthyes: Gymnotidae). Molecular Phylogenetics and Evolution, in press.

Maldonado-Ocampo, J. A. \& J. S. Albert. 2003. Species diversity of gymnotiform fishes in Colombia. Biota Colombiana, 4: 147165.

Ribeiro, A. C. 2006. Tectonic history and the biogeography of the freshwater fishes from the coastal drainages of eastern Brazil: an example of faunal evolution associated with a divergent continental margin. Neotropical Ichthyology, 4(2): 225-246.

Richer-de-Forges, M. M., W. G. R. Crampton \& J. S. Albert. 2009. A new species of Gymnotus (Gymnotiformes, Gymnotidae) from Uruguay: description of a model species in neurophysiological research. Copeia, 2009(3): 538-544.

Taylor, W. R. \& G. C. van Dyke. 1985. Revised procedures for staining and clearing small fishes and other vertebrates for bone and cartilage study. Cybium, 9: 107-119.

Westaway, R. 2006. Late Cenozoic sedimentary sequences in Acre state, southwestern Amazonia: Fluvial or tidal? Deductions from the IGCP 449 field trip. Journal of South American Earth Sciences, 21: 120-134.

Accepted September 22, 2009 Published December 18, 2009 